\title{
How the erosion of our public health system hobbled England's covid-19 response
}

\author{
Tensions with government, challenges in collaborating with the NHS, and the legacy of savage cuts
} have all hampered the important role of public health in the pandemic. Richard Vize reports

\section{Richard Vize}

London

The covid-19 pandemic has laid bare the impact of years of spending cuts and muddled structural reforms on the effectiveness of England's public health services. It has also shown that their current position within local government is the best place for them but that they need clearer national leadership.

\section{The 2012-13 reforms}

Under the reforms implemented in 2013 by the then health secretary, Andrew Lansley, in the Health and Social Care Act 2012, public health in England moved back into local government, where it had been until 1974. Directors of public health became the strategic leaders tasked with a remit to tackle local health inequalities, as well as commissioning services including sexual health, smoking cessation, drug and alcohol services, and early years support for children, such as through school nursing and health visitors.

Public Health England was created to oversee emergency preparedness, health protection such as communicable disease control, and public health campaigns, as well as supporting local systems with data and evidence. It was an executive agency of the Department of Health, not an independent body. ${ }^{1}$

However, the NHS retained some aspects of public health-notably, vaccinations and immunisation, and the chief medical officer remained the lead advocate for public health throughout government and leader of the public health profession.

While most of Lansley's reforms were heavily criticised, putting public health back into local government is widely regarded as having been the right approach. Jeanelle de Gruchy, director of population health at Tameside Council and president of the Association of Directors of Public Health, says, "Being in local government is crucially important in terms of getting close to local communities. You're working incredibly closely with social services, and at the same time we have strong links to the local NHS and the GPs, so you've got those links locally between local government and the hospitals, and that's certainly better than it was before."

\section{Communicable disease cut away}

But the carving off of communicable disease control into Public Health England has been far less successful. Helen Walters, now public health consultant adviser at the National Institute for Health Research, was head of health at the Greater London Authority while the Lansley reforms were being implemented and was public health director for NHS Westminster under the previous system. She believes that moving communicable disease control staff away from public health directors has affected the response to the covid-19 pandemic.

She says, "Under the old [pre-2013] system there was a closeness between the director of public health and the local communicable disease control people. Mine was on the same corridor. That was lost a bit in the reforms because the communicable disease people went to Public Health England.

"They [the local communicable disease control people] did all the emergency planning: influenza, pandemic planning, and outbreak control. If you were a director of public health and a question on it came along you would have an experienced consultant on your team. Now they're not sitting in the team."

She explains, "Public health directors understand the bigger system, but they don't understand the infectious disease side so well, so [now] you've got to get that expertise from Public Health England. They become less local. Understanding the local population helps hugely if you're trying to organise contact tracing or a large testing mechanism, so that's going to make it more difficult."

\section{Weaknesses and tensions}

The covid pandemic has exposed two key fault lines of the public health system: weaknesses in local collaboration between 
the NHS and councils, and tensions between the local and national parts of the system.

When NHS England unveiled its long term plan last year, with proposals for a bigger NHS role in commissioning sexual health services, health visitors, and school nurses, local public health directors bristled at what they saw as an attempted land grab. ${ }^{2}$

De Gruchy says that it was seen as "wanting to do it all themselves, and so you have the danger of trying to recreate public health within the NHS, but not actually understanding or drawing on the expertise of public health."

She traces the difficulties in understanding local implementation back to 2003, when the Health Protection Agency was established to take over work on infectious diseases from the health authorities. Most of the agency was eventually absorbed into Public Health England.

"There is a story about the disconnect between national and local," she says. "You already start to see the local going up into a sort of regional structure. It's that local knowledge and expertise of communities and how [policy] is playing out that is so crucial to ensuring that we have a good health protection response locally."

\section{Test, track, and trace: national policy to local delivery}

For many public health teams the confusion, delays, and policy changes over the "test, track, and trace" plans to control the spread of covid-19 exemplify the lack of understanding at the national level about how to make policy work locally.

Allyson Pollock, professor of public health at Newcastle University, refers to a widely quoted number of contacts traced from 590 confirmed cases. "Contact tracing stopped on 12 March, and they'd only traced 3500 contacts," she says. "That's pretty poor. They said first of all it was ineffective, and secondly they didn't have the resource. But one leads to the other.

"And yet they managed to throw hundreds of millions of pounds at high tech solutions and [the Nightingale temporary] hospitals. They focused very much on the acute sector but neglected the community sector, which is where all the public health happens."

De Gruchy says, "When it comes to testing and contact tracing, policy has been set at national level, and then locally we are all having to implement it. You have the Public Health England and NHS testing, working through the Department of Health and Social Care; then you have the Office for Life Sciences working with Deloitte and others, which was totally disconnected from the other testing. You are told the night before that you're going to have a testing site in Manchester, and Deloitte is running it.

"So, you have two national initiatives that come down and arrive, and you get told about the night before. What do we do with the results? What's the clinical governance? We didn't have any input or say. So, what you get is the situation we have now in Greater Manchester, where we have five different testing sites that we have to try to marry up."

There is some evidence of government getting the message that it needs a better understanding of how national policy plays out locally. A letter from Public Health England on 24 April explaining the developing policy on contact tracing emphasised the discussions with public health representatives and local government.

\section{Information sharing and the second wave}

However, the fractures between national policy and local delivery, and between the NHS and local government, are evident in the repeated failures to share information during the pandemic. Jim McManus, director of public health for Hertfordshire County Council, says that one of the council's biggest concerns is "NHS England sharing of data. The partnership [with] NHS England could and ought to have been better."

De Gruchy complains that, "despite leading so much of this work, [public health directors are] left off time and time again from key communications or guidance development by NHS England and some government departments. It's not good enough, and it slows our response at a time when we can least afford it.

"It tells us how dominant the NHS is in terms of politicians' and the public's understanding about what health is, and how we get to have good health. Health is [seen to be] about the NHS. And the NHS struggles to integrate within itself, never mind with other parts of the public sector-it struggles to work in partnership. And, with public health having moved into local government, that is an issue."

The biggest test for sharing and using data will come with the expected second wave of covid-19. De Gruchy says that preparations for second and subsequent waves of the virus need to be "massive and long term."

She says, "The data flows from testing into the local system need to be clear. At the moment all the results are in different systems. There is a lack of clarity on who's been tested and what the results are. To do contact tracing you need a slick testing programme."

\section{Legacy of austerity}

But the biggest problem facing public health services is not coordination with the NHS or working with government, but money and staffing. A King's Fund analysis reveals that like-for-like public health spending in cash terms was virtually the same in 2019-20 as in 2013-14. ${ }^{3}$ The Health Foundation says that this translates into a reduction of almost $25 \%$ in spending per person from 2014-15 to 2019-20. ${ }^{4}$

De Gruchy says, "At the same time as the transition to local government you had these massive cuts, so a lot of people retire and leave. And there are fewer people to deliver, so there is no surge capacity."

Cuts to other local government services, such as environmental health-which has an important role to play in contact tracing — and emergency planning, have further undermined public health. De Gruchy concludes, "So, prevention and preparedness are two areas that have been quite affected by the cuts, despite the rhetoric around prevention."

McManus says, "There is no doubt local government is the right place for us [directors of public health] to be in England. But there is also no doubt that the austerity has hampered us. Had the cuts not happened, we would have had more staff that we could have put in at a faster and harder pace. We would have had many more health visitors and school nurses."

Around 170 clinicians from the clinical services McManus commissions have gone into the NHS response to covid-19, leaving around 200 to continue existing services and be redeployed to other public health roles. Before 2013 there would have been around 400 left. Services that have been hit include 
mental health services for children and young people despite concerns that the lockdown is undermining mental health.

Walters says, "I don't think it's been the reorganisation per se-it's been government austerity that's the problem. It's the boots on the ground. With sufficient funding, the current structures would work fine."

\section{Long term covid-19 planning}

Walters believes that the lack of capacity in public health teams is undermining their ability to plan for coping with covid-19 in the long term. "The average public health team will be smaller," she explains. "If you're a director of public health and you have five public health consultants underneath you, you can say to one, 'I don't want you to think about the acute phase, I want you to be thinking about recovery.' If you've only got two consultants you can't afford to do that: you're just dealing with what's urgent. It's about having that space in the system to be thinking ahead."

Cuts have also hit Public Health England and NHS England, affecting services such as health protection, screening, and immunisation. Public Health England's regional teams are thinly staffed, so they have been calling for council staff to help them out. Pollock says, "You've got Public Health England operating out of nine regional hubs servicing more than 300 local authorities, and there is simply not enough capacity."

Inadequate staffing comes on the back of the longstanding erosion of data collection and analysis since the creation of the internal market in 1991, says Pollock, which has impacted on England's ability to respond to covid-19. "We've currently got this terrible debacle in the pandemic with nursing homes and social care - we used to collect a lot more data from them, and that was culled. That was partly because of so much privatisation [of care homes] that the government couldn't see any value in it. It doesn't have data on staff or on the residents or their level of need." Pollock believes that, had this information still been collected, the danger facing care home residents could have been identified sooner and NHS resources and staff mobilised to support them.

But, despite the tensions with government, the challenges in collaborating with the NHS, and the savage cuts, there is little doubt among public health directors that local government is the best place for their service. Reflecting on his experiences during the pandemic, McManus says, "I can see the collaboration between the local resilience forum and the Ministry of Housing, Communities and Local Government, the Ministry of Defence, police, local media, and a whole range of agencies. It's brilliant; it's far better than it would have been in the NHS, because I am connected into a range of organisations and expertise with a different perspective.

"As a director of public health I look right across the whole spectrum of issues in the community, from PPE and testing, running a hotline for schools, running a whole load of work in care homes, right through to advising on what the curve of the epidemic means for recovery. We've got stuck in far more than we would have been in the NHS."

Walters believes that the pandemic could prompt a reassessment of the role of public health in the nation's life. She says, "It has given public health a profile which invites an examination by the country on how much we value it, and how much money we're spending on it. It's been undervalued compared with all the other medical specialties for a long time.

"This has focused the eyes of the country on something that was fairly invisible before. It gives us an ideal opportunity to think about where we, as a society, want to place public health." (See box 1.)

\section{Box 1: Government and NHS responses}

In response to the comments presented in this article, Public Health England said: "Rest assured that public health advice offered by Public Health England is at the heart of government, with a range of public health specialists advising Sage [Scientific Advisory Group for Emergencies], CMO [chief medical officer] and ministers from across all departments. The public health system is playing a vital role in what is rightly a truly national, multi-agency response."

The Department of Health and Social Care said: "This is an unprecedented global pandemic and we have taken the right steps at the right time in order to protect the NHS and save lives. This government has been working with a world renowned team of scientists, clinicians and public health experts.

"We have ramped up testing, overhauled the way PPE is being delivered to those who need it and helped the NHS cope with increased demand."

NHS England acknowledged receipt of an email presenting it with the comments but has not responded.

\section{Pandemic planning without public health}

Public health experts are concerned that the sector's voice has been lost in much of the government's discussion about how to handle the pandemic, drowned out by epidemiologists and scientific advisers.

Pollock says, "The people who should be in charge of the policy should be the communicable disease control experts and public health. They have an overview of the system. It's regrettable that the chief medical officers are no longer from public health in England and Scotland, because you need to understand the system at every single level.

"They'd have trained in most parts of the system, so they would have understood the importance of the local and the bottom-up-and how centralised, top-down approaches don't work." (See timeline in box 2.)

\footnotetext{
Box 2: Timeline

Slow decline: key moments in England's public health in recent decades

1974 Control of public health moves from local authorities to the new health authorities

1991 The purchaser-provider split and creation of the internal market. Health authorities lose power to trusts

2003 The Health Protection Agency is established to take over infectious diseases from health authorities

2010 The chief medical officer (CMO) for England, Liam Donaldson, a former regional public health director, retires; Sally Davies, a haematologist without a background in public health, takes the post

2012 The Health and Social Care Act defines the most widespread reforms to the NHS since its inception in 1948

2013 April brings into force the main changes of the Health and Social Care Act 2012, among them the move of public health back to local government .

. however, a national government agency, Public Health England, is created to oversee elements including emergency preparedness and health protection. The NHS retains some aspects of public health, including vaccinations and immunisation

2019 NHS England unveils its long term plan. Public health directors sense a power grab, with proposals for a bigger NHS role in commissioning sexual health services, health visitors, and school nurses

2019 Chris Whitty, an epidemiologist, becomes CMO-but he retains his role as chief scientific adviser to the Department of Health and Social Care, with responsibilities including health research and development and the life sciences strategy

2019-20 Public health spending has fallen in real terms by $25 \%$ per person over the past five years
}

Over the past month the national media have gradually exposed the hitherto secret membership of the government's emergency scientific advisory group, Sage. Public Health England has three representatives among the 50 strong core of the group, but the evidence it considers and the advice it gives remain hidden. 
Maggie Rae, president of the Faculty of Public Health, calls for more openness. "It would be helpful if we had more transparency," she says. "If the evidence is published and people have a chance to challenge that effectively, it is probably a better strategy. Openness leads to trust, and trust is what we want at the moment."

When Chris Whitty took up the post of chief medical officer (CMO) for England in 2019 he retained his role as chief scientific adviser to the Department of Health and Social Care, with responsibilities including health research and development and its life sciences strategy. His predecessor as CMO, Sally Davies, also held both roles for a while.

Mike Gill, former regional director of public health for southeast England, believes that this expansion of responsibilities has reduced the importance of public health at the centre of government. He compares it with the time before the 2013 reorganisation, when the CMO was Liam Donaldson, a former regional public health director. "He had direct responsibility for the public health function across the country," says Gill, "and that meant he related to the regional directors of public health, and to the directors of public health at local level; and he was, for example in the H1N1 outbreak, unambiguously the professional lead."
He adds that, now, Public Health England reports to a director general in the Department of Health and Social Care, NHS England retains parts of public health, and "the chief medical officer does not have any direct line relationship with the public health function. Instead you have a plurality of leadership figures, which is inevitably the cause of indecision and muddle."

Gill believes that the government should immediately give Whitty de facto control of Public Health England.

Competing interests: I have read and understood BMJ policy on declaration of interests and have no relevant interests to declare.

Provenance and peer review: Commissioned; not externally peer reviewed.

1 Buck D. The English local government public health reforms: an independent assessment. King's Fund. 2020. https://www.kingsfund.org.uk/publications/local-government-publichealth-reforms.

2 NHS England. The NHS long term plan. 2019. https://www.longtermplan.nhs.uk.

3 Buck D. The English local government public health reforms: an independent assessment. King's Fund. 2020. https://www.kingsfund.org.uk/publications/local-government-publichealth-reforms.

$4 \quad$ Finch D, Bibby J, Elwell-Sutton T. Taking our health for granted: plugging the public health grant funding gap. Health Foundation. 2018. www.health.org.uk/publications/taking-ourhealth-for-granted.

Published by the BMJ Publishing Group Limited. For permission to use (where not already granted under a licence) please go to http://group.bmj.com/group/rights-licensing/ permissions 